\title{
PENGARUH MODAL USAHA DAN STRATEGI PEMASARAN TERHADAP PENGEMBANGAN USAHA MIKRO DI KECAMATAN KABILA KABUPATEN BONE BOLANGO
}

\author{
Arniati lasoma \\ Ekonomi Syariah, IAIN Sultan Amai Gorontalo \\ arnilasoma@gmail.com \\ Sofhian \\ Ekonomi Syariah, IAIN Sultan Amai Gorontalo \\ sofhian@iaingorontalo.ac.id \\ Yusran Zainuddin \\ Manajemen Keuangan Syariah, IAIN Sultan Amai Gorontalo \\ yusranzainuddin@iaingorontalo.ac.id
}

\section{Abstrak}

Penelitian ini dilatarbelakangi oleh terdapatnya 1205 pelaku usaha mikro di Kecamatan Kabila, Kabupaten Bone Bolango dengan peluang dan potensi yang besar untuk dapat berkembang. Penelitian ini bertujuan untuk mengetahui pengaruh modal usaha dan strategi pemasaran terhadap pengembangan usaha mikro di Kecamatan Kabila Kabupaten Bone Bolango. Penelitian ini adalah jenis kuantitatif dengan metode yang digunakan deskriptif dan pendekatan kuantitatif. Sehingga teknik analisis data yang digunakan adalah uji statistik dengan analisis regresi linear berganda, koefisien determinasi, korelasi berganda, dan uji hipotesis. Jumlah populasi pada penelitian ini adalah 1205 usaha mikro, dengan sampel penelitian yang digunakan adalah 93 usaha mikro. Hasil penelitian yang telah diperoleh menyimpulkan bahwa secara parsial modal usaha berpengaruh signifikan terhadap pengembangan usaha mikro di Kecamatan Kabila Kabupaten Bone Bolango; strategi pemasaran berpengaruh signifikan terhadap pengembangan usaha mikro di Kecamatan Kabila Kabupaten Bone Bolango; dan secara simultan modal usaha dan pengembangan usaha berpengaruh terhadap pengembangan usaha mikro di Kecamatan Kabila Kabupaten Bone Bolango, dengan kontribusi sebesar $28,6 \%$, sedangkan sisanya $71.4 \%$ dipengaruhi oleh faktor lain seperti tenaga kerja, dan keuntungan yang didapat oleh pelaku usaha mikro itu sendiri.

Kata Kunci : Modal Usaha, Strategi Pemasaran, Pengembangan Usaha Mikro, Kecamatan Kabila, Kabupaten Bone Bolango

\footnotetext{
Abstract

Bone Bolango Regency with great opportunities and potential to develop. This study aims to determine the effect of venture capital and marketing strategy on the development of micro-enterprises in Kabila District, Bone Bolango Regency. This research is a quantitative type with descriptive and quantitative methods used. So the data analysis technique used is statistical test with multiple linear regression analysis, coefficient of determination, multiple correlation, and hypothesis testing. The total population in this study was 1205 micro enterprises, with the research sample used were 93 micro enterprises. The results of the research that have been obtained conclude that partially business capital has a significant effect on the
} 
development of micro-enterprises in Kabila District, Bone Bolango Regency; marketing strategy has a significant effect on the development of micro-enterprises in Kabila District, Bone Bolango Regency; and simultaneously business capital and business development affect the development of micro-enterprises in Kabila District, Bone Bolango Regency, with a contribution of $28.6 \%$, while the remaining $71.4 \%$ is influenced by other factors such as labor, and the profits obtained by the micro-enterprises themselves.

\section{Keywords : Business Capital, Marketing Strategy, Micro Business Development, Kabila District, Bone Bolango Regency}

\section{Pendahuluan}

Perekonomian saat ini digerakkan oleh pelaku pelaku usaha, salah satunya usaha mikro. Usaha mikro adalah sebuah usaha milik perorangan yang sifatnya semata-mata untuk mencari nafkah dan memperoleh keuntungan (Hapsari, 2019). Usaha mikro termasuk kategori yang tergolong paling kecil yaitu omset paling banyak Rp 50 juta(tidak termasuk tanah dan bangunan tempat usaha) dan hasil penjualan paling banyak 300 juta (Sururi, Hasanah, Mulyasih, Firdaus, Hasuri, \& Yuliani, 2020). Menurut Bank Indonesia dalam Sururi, dkk. (2020) usaha mikro adalah usaha yang dimiliki oleh rakyat yang tergolong miskin. Salah satu ciri-ciri usaha mikro yaitu jenis barang dari usahanya tidak selalu menetap begitupun dengan tempat usaha yang tidak menetap sewaktu-waktu dapat berganti. Namun usaha mikro memiliki keunggulan seperti mudah dijalankan, modal kecil tapi untung besar, dan pemasaran dilingkup yang kecil dan mudah. (Sururi, Hasanah, Mulyasih, Firdaus, Hasuri, \& Yuliani, 2020)

Usaha mikro memiliki peranan penting dalam memajukan perekonomian di Indonesia. Pentingnya peran usaha mikro tersebut membuat negara berupaya untuk mengembangkan usaha mikro (Safitri \& Setiaji, 2018). Pengembangan suatu usaha adalah tanggung jawab dari setiap pelaku usaha atau para wirausaha yang membutuhkan pandangan kedepan, motivasi dan kreativitas, serta dapat meningkatkan kepuasan pelanggan. (Sanawiri \& Iqbal, 2018). Menurut Schnaars, dalam jurnal Arkani dan Muhibbuddin (2021:20) tujuan bisnis adalah untuk membuat pelanggan merasa puas. (Arkani \& Muhibbin, 2021)

Sebuah usaha memerlukan pengembangan untuk memperluas dan mempertahankan usaha tersebut agar dapat bertahan dan berjalan dengan baik. Untuk melaksanakan pengembangan usaha dibutuhkan dorongan dari berbagai aspek seperti bidang produksi dan pengolahan, pemasaran, sumber daya manusia dan lain-lain.

Sebagaimana apa yang dinyatakan dalam (Ajuna, 2020:247) bahwa "para pelaku usaha memberikan harapan kepada para pelanggannya untuk terus memberikan kepuasan melalui inovasi dan pengembangan produk yang lebih berkualitas" (Ajuna, 2020)

Menurut Hubaeis (2009), untuk mengembangkan usaha menjadi lebih baik, pelaku usaha harus memperhatikan faktor-faktor yang dapat mempengaruhi pengembangan usaha itu sendiri. Faktor-faktor tersebut antara lain, permodalan, produksi, pemasaran, dan sumber daya manusia. (Widjadja, Alamsyah, Rohaeni, \& Sukanjie, 2018). Dari beberapa faktor yang mempengaruhi pengembangan usaha, terdapat salah satu diantaranya adalah modal usaha dan strategi pemasaran. Artinya modal usaha dan strategi pemasaran adalah hal yang penting untuk diperhatikan dalam mengembangkan suatu usaha. 
Modal usaha merupakan sebagian dan yang akan dipergunakan untuk kebutuhan pokok dalam memulai usaha, dipinjamkan dan atau sebuah harta benda yang digunakan untuk menghasilkan sesuatu sehingga dapat menambah kekayaan. Modal usaha adalah unsur terpenting dalam mengelola dan mengembangkan sebuah usaha. Jika modal bertambah maka penghasilan yang didapatkan lebih banyak. (Istinganah \& Widiyanto, 2020)

Selain modal usaha, dalam meningkatkan pengembangan usaha, pelaku usaha perlu meningkatkan strategi pemasaran. Strategi pemasaran adalah salah satu cara yang dapat menjadi pemenang dalam bersaing secara berkesinambungan baik itu untuk perusahaan yang menghasilkan barang atau jasa. Dalam mengembangkan strategi pemasaran, yang harus dapat diterapkan adalah 4P : Product (produk), Price (harga), Place (tempat), dan Promotion (promosi). Tujuan dari pemasaran adalah menghasilkan barang atau jasa yang bernilai tinggi sehingga dibutuhkan oleh konsumen agar mereka menyukai dan membelinya. Dan dapat bersaing dengan usaha yang lain. (Nuraisiah, 2021)

Jumlah UMKM di Indonesia sebanyak 52,9 juta pelaku. Kementrian Koperasi UMKM melansir sebanyak 3,79 juta usaha mikro, kecil dan menengah sudah memanfaatkan platform online dalam memasarkan produknya. Berdasarkan data ini dapat disimpulkan bahwa umkm di Indonesia semakin berkembang. (Ayuwuragil, 2017). Hal ini dikarenakan masyarakat sadar dengan banyaknya keuntungan yang akan didapatkan ketika menjalankan umkm. Begitu pula yang dilakukan oleh masyarakat pada Kabupaten Bone Bolango. Banyak masyarakat yang berlomba-lomba membangun untuk membangun usaha meskipun masih dikategorikan usaha mikro, tetapi mereka masih menekuni usaha tersebut demi memperoleh keuntungan untuk keberlangsungan hidup mereka.

Kabupaten Bone Bolango terdiri dari 18 kecamatan dengan perkembangan usaha mikro yang dikatakan cukup optimal. Hal ini dikarenakan dari tahun 2016 sampai tahun 2020 jumlah usaha mikro semakin bertambah.

Tabel Perkembangan Usaha Mikro Kabupaten Bone Bolango Tahun 2016-2020

\begin{tabular}{|cc|}
\hline TAHUN & JUMLAH USAHA MIKRO \\
\hline $\mathbf{2 0 1 6}$ & 2.696 \\
\hline $\mathbf{2 0 1 7}$ & 2.766 \\
\hline $\mathbf{2 0 1 8}$ & 2.776 \\
\hline $\mathbf{2 0 1 9}$ & 4.689 \\
\hline $\mathbf{2 0 2 0}$ & 8.335 \\
\hline
\end{tabular}

Sumber: DataDisperindag Koperasi dan UMKM Kab. Bone Bolango

Dari tahun ke tahun adanya penumbuhan wira usaha baru dari usaha mikro. Faktor pendorong yang memicu bertambahnya usaha mikro antara lain: adanya pembinaan yang dilakukan secara kontinyu oleh Disperindag Koperasi dan UMKM Kab. Bone Bolango serta diklat pelatihan kewirausahaan bagi para pelaku usaha.

\section{Tabel Data Jumlah Usaha Mikro Setiap kecamatan}

Tahun 2020

\begin{tabular}{|llc|}
\hline NO & KECAMATAN & JUMLAH USAHA MIKRO \\
\hline 1. & Bone & 517 \\
\hline 2. & Bone Pantai & 304 \\
\hline
\end{tabular}




\begin{tabular}{|llc|}
\hline $\mathbf{3 .}$ & Bone Raya & 191 \\
\hline $\mathbf{4 .}$ & Botupinge & 462 \\
\hline $\mathbf{5 .}$ & Bulango Selatan & 762 \\
\hline $\mathbf{6 .}$ & Bulango Timur & 456 \\
\hline $\mathbf{7 .}$ & Bulango Ulu & 5 \\
\hline $\mathbf{8 .}$ & Bulango Utara & 151 \\
\hline $\mathbf{9 .}$ & Bulawa & 212 \\
\hline $\mathbf{1 0 .}$ & Kabila & 1205 \\
\hline $\mathbf{1 1 .}$ & Kabila Bone & 1036 \\
\hline $\mathbf{1 2 .}$ & Pinogu & 54 \\
\hline $\mathbf{1 3 .}$ & Suwawa & 384 \\
\hline $\mathbf{1 4 .}$ & Suwawa Selatan & 126 \\
\hline $\mathbf{1 5 .}$ & Suwawa Tengah & 604 \\
\hline $\mathbf{1 6 .}$ & Suwawa Timur & 413 \\
\hline $\mathbf{1 7 .}$ & Tapa & 395 \\
\hline $\mathbf{1 8 .}$ & Tilongkabila & 1058 \\
\hline & Jumlah & $\mathbf{8 3 3 5}$ \\
\hline
\end{tabular}

Sumber: data primer diolah, Disperindagkum Kabupaten Bone Bolango

Berdasarkan data dari Disperindag dan UMKM Kabupaten Bone Bolango, Kecamatan Kabila merupakan kecamatan yang memiliki usaha mikro yang paling banyak di Kabupaten Bone Bolango dengan jumlah 1205 pelaku usaha mikro. Kecamatan Kabila mempunyai peluang dan potensi yang lumayan besar dalam bidang perdagangan, kerena letaknya yang berbatasan dengan pusat Kota Gorontalo. Daerah ini mempunyai beragam usaha mikro yang tersebar di berbagai desa dan kelurahan. Banyak sekali pedagang kecil seperti warung, usaha kuliner, online shop, dan sebagainya. Dari usaha yang masih berbentuk usaha pinggiran hingga sudah yang berbentuk toko.

Menurut Dwi Riyanti (2003), suatu usaha dikatakan berkembang dilihat dari beberapa standar yaitu: bertambahnya jumlah produksi, bertambahnya jumlah pelanggan, perluasan daerah pemasaran, dan bertambahnya pendapatan usaha. (Riyanti, 2003). Di Kecamatan kabila, terdapat banyak usaha mikro yang sudah dapat dikategorikan berkembang, hal ini dapat dilihat dari terpenuhinya standar-standar berkembangnya usaha menurut teori Dwi Riyanti, seperti memperbesar lapak, menambah beberapa barang baru yang banyak dicari oleh pembeli, dan penjual yang awalnya belum memiliki lapak sudah membuat lapak sendiri.

Meskipun usaha mikro sudah bisa mencapai target dari segi jumlah usaha, tetapi masih terdapat permasalahan yang kerap dialami untuk meningkatkan perkembangan usaha mikro. Dari beberapa usaha mikro yang sempat diwawancara sebagai data awal yaitu dengan kendala yang hampir sama diantaranya : pertama, minimnya modal usaha yang jadi dasar permasalahan dalam usaha mikro. Kebanyakan pelaku usaha mikro masih kesulitan dalam memperoleh sumber modal. Hal ini dikarenakan para pelaku usaha mikro hanya mengandalkan kantong pribadinya dan tidak ingin meminjam di lembaga keuangan.

Kedua, strategi pemasaran yang belum optimal. Hal ini disebabkan dengan banyaknya pelaku usaha mikro hanya menjual produk atau jasa dilingkungan tempat 
mereka tinggal saja. Karena kurangnya promosi yang dilakukan oleh para pelaku usaha mikro. Ketiga, pengelolaan keuangan yang tidak efisen. Para pelaku usaha mikro masih menggunakan pembukuan secara manual dan sebagian tidak mencatat penerimaan dan pendapatan usahanya.

Untuk itu dengan melihat fenomena yang ada maka peneliti tertaritk melakukan penelitian untuk melakukan penelitian tentang mengapa banyak usaha mikro di Kecamatan Kabila Kabupaten Bone Bolango mengalami perkembangan usaha. Apakah perkembangan tesebut dipengaruhi oleh modal usaha, dan strategi pemasaran atau justru dipengaruh oleh faktor lainmengalami penurunan sebesar 0,13\%, dan tahun 2020 terjadi penurunan lagi sebesar $0,04 \%$.

Maka dari itu, artikel ini bertujuan untuk menganalisis pengaruh modal usaha dan strategi pemasaran terhadap pengembangan usaha mikro di Kecamatan Kabila Kabupaten Bone Bolango. Berdasarkan latar belakang masalah dan tujuan penelitian ini, maka dibuatlah sebuah hipotesis:

a. Modal Usaha terhadap Pengembangan Usaha

H1: Modal usaha berpengaruh terhadap pengembangan usaha

b. Strategi pemasaran terhadap Pengembangan Usaha

H2: Strategi pemasaran berpengaruh terhadap pengembangan usaha

c. Modal Usaha dan Strategi Pemasaran terhadap Pengembangan Usaha

H3: Modal usaha dan strategi pemasaran berpengaruh terhadap terhadap pengembangan usaha

\section{Metode}

Metode dan pendekatan yang digunakan dalam penelitian ini yaitu metode deskriptif dengan pendekatan kuantitatif. Objek dalam penelitian ini adalah Usaha Mikro yang ada di Kecamatan Kabila Kabupaten Bone Bolango. Waktu penelitian ini berlangsung kurang lebih tiga bulan yaitu bulan Mei-Juli 2021. Jenis dan sumber data dalam penelitian ini adalah menggunakan data primer dan data sekunder. Sedangkan teknik pengumpulan data dengan cara Observasi, pembagian kuesioner, dan dokumentasi. populasi dalam penelitian adalah seluruh usaha mikro di Kecamatan Kabila Kabupaten Bone Bolango yang berjumlah 1205 usaha mikro. Untuk sampel dalam penelitian ini diambil berdasrkan rumus slovin, sehingga:

$$
\begin{gathered}
n=\frac{\mathrm{N}}{\mathrm{N} \cdot \mathrm{d}^{2}+1} \\
=\frac{1205}{1205 \cdot(0 \cdot 10)^{2}+1}=92,33 \approx 93
\end{gathered}
$$

Berdasarkan perhitungan tersebut jumlah sampel yang akan diteliti dan yang akan dibagikan kuesioner adalah sebanyak 93 usaha mikro yang ada di Kecamatan Kabila. Adapun teknik sampling yang digunakan dalam penelitian ini adalah simple random sampling dan proportionate stratified random sampling. Dengan demikian maka jumlah sampel yang harus diambil yaitu 53 nasabah.

Data yang digunakan merupakan data primer, dimana data diperoleh dari hasil kuesioner yang telah diisi oleh responden. Teknik analisis data menggunakan regresi berganda, koefisien determinasi, dan pengujian hipotesis. Selain itu juga digunakan uji validitas, reliabilitas, dan normalitas data untuk melihat keadaan data penelitian valid, reliebel, dan normalitas atau tidak. 


\section{Hasil dan Pembahasan}

Hasil penelitian merupakan bagian yang menyajikan bagian generik dan uraian data yang ditemukan berdasarkan output dalam penelitian. Hasil penelitian ini yaitu mengenai uji validitas dan reliabilitas, uji normalitas data, analisis kuantitatif dan analisis uji hipotesis yang di uji dengan alat statistik yaitu Software SPSS for Windows V.25.0.

\subsection{Uji Validitas dan Reliabilitas}

\subsubsection{Uji Validitas}

Berikut hasil uji validitas instrumen kuesioner modal usaha, strategi pemasaran, dan pengembangan usaha mikro.

\section{Tabel 1. Hasil Uji Validitas}

\begin{tabular}{|c|c|c|c|c|c|}
\hline No. & Pernyataan & $\begin{array}{c}\text { Total } \\
\text { Correlation }\end{array}$ & $\begin{array}{l}\text { Sig. (2- } \\
\text { Tailed) }\end{array}$ & $\mathbf{N}$ & Ket \\
\hline \multicolumn{6}{|c|}{ Variabel Modal (X1) } \\
\hline 1. & $\begin{array}{l}\text { Modal awal yang saya } \\
\text { gunakan untuk membangun } \\
\text { usaha adalah modal dari } \\
\text { tabungan sendiri }\end{array}$ & $0.595^{* *}$ & 0.00 & 93 & valid \\
\hline 2. & $\begin{array}{l}\text { Dalam mengembangkan } \\
\text { usaha saya menggunakan } \\
\text { modal pinjaman }\end{array}$ & $0.550^{* *}$ & 0.00 & 93 & valid \\
\hline 3. & $\begin{array}{l}\text { Besaran modal yang saya } \\
\text { gunakan pada usaha sangat } \\
\text { berpengaruh pada pendapatan } \\
\text { usaha saya }\end{array}$ & $0.690^{* *}$ & 0.00 & 93 & valid \\
\hline 4. & $\begin{array}{l}\text { Adanya tambahan modal dari } \\
\text { luar akan menjadikan usaha } \\
\text { saya lebih maju dan } \\
\text { berkembang }\end{array}$ & $0.520^{* *}$ & 0.00 & 93 & valid \\
\hline \multicolumn{6}{|c|}{ Variabel Strategi Pemasaran (X2) } \\
\hline 1. & $\begin{array}{l}\text { Harga produk yang saya } \\
\text { tawarkan sangat terjangkau }\end{array}$ & $0.807^{* *}$ & 0.00 & 93 & valid \\
\hline 2. & $\begin{array}{l}\text { Saya selalu melakukan inovasi } \\
\text { produk pada usaha yang saya } \\
\text { jalankan }\end{array}$ & $0.828^{* *}$ & 0.00 & 93 & valid \\
\hline 3. & $\begin{array}{l}\text { Saya memiliki tempat } \\
\text { penjualan lebih dari satu }\end{array}$ & $0.292^{* *}$ & 0.00 & 93 & valid \\
\hline 4. & $\begin{array}{l}\text { Saya melakukan promosi } \\
\text { penjualan melalui, postingan } \\
\text { sosial media dan word of mouth }\end{array}$ & $0.508^{* *}$ & 0.00 & 93 & valid \\
\hline \multicolumn{6}{|c|}{ Variabel Pengembangan Usaha (Y) } \\
\hline 1. & $\begin{array}{l}\text { Pendapatan omset penjualan } \\
\text { dari usaha saya dapat } \\
\text { memperbanyak produk yang } \\
\text { dijual }\end{array}$ & $0.580^{* *}$ & 0.00 & 93 & valid \\
\hline 2. & $\begin{array}{l}\text { Dengan berkembangnya } \\
\text { jumlah tenaga kerja dapat } \\
\text { mendorong saya untuk lebih }\end{array}$ & $0.884^{* *}$ & 0.00 & 93 & valid \\
\hline
\end{tabular}




\begin{tabular}{|c|c|c|c|c|c|}
\hline & mengembangkan usaha & & & & \\
\hline 3. & $\begin{array}{l}\text { Dengan meningkatnya jumlah } \\
\text { pelanggan dapat mendorong } \\
\text { saya untuk mengembangkan } \\
\text { usaha }\end{array}$ & $0.702^{* *}$ & 0.00 & 93 & valid \\
\hline
\end{tabular}

Sumber: Output SPSS versi 23.0

Berdasarkan tabel diatas dapat diketahui bahwa 11 item pernyataan yang digunakan untuk mengukur modal usaha, strategi pemasaran, dan pengembangan usaha semuanya dikatakan valid.

\subsubsection{Uji Reliabilitas}

Berikut hasil uji reliabilitas instrumen kuesioner modal usaha, strategi pemasaran, dan pengembangan usaha mikro.

\section{Tabel 2. Hasil Uji Reliabilitas}

\begin{tabular}{|c|c|c|c|}
\hline No. & Variabel & Reliabilitas & Keterangan \\
\hline 1. & X1 & 0.706 & Reliabel \\
\hline 2. & X2 & 0.696 & Reliabel \\
\hline 3. & Y & 0.784 & Reliabel \\
\hline
\end{tabular}

Sumber: Output SPSS versi 23.0

Pada hasil uji reliabilitas instrumen modal usaha diperoleh nilai sebesar 0.706, dan strategi pemasaran diperoleh nilai sebesar 0.696, sedangkan pada instrument pengembangan usaha diperoleh nilai sebesar 0.784. dengan demikian ketiga instrument dapat dikatakan reliable karena mempunyai nilai koefisien Alpha yang lebih besar daripada harga kritik 0.60 .

\subsection{Uji Normalitas Data}

Uji normalitas merupakan salah satu komponen perhitungan dari asumsi klasik yang mana digunakan untuk menilai apakah penelitian memiliki sebaran data yang normal atau tidak. Berikut ini adalah hasil uji normalitas data, untuk melihat apakah ketiga variabel memiliki sebaran data yang normal.
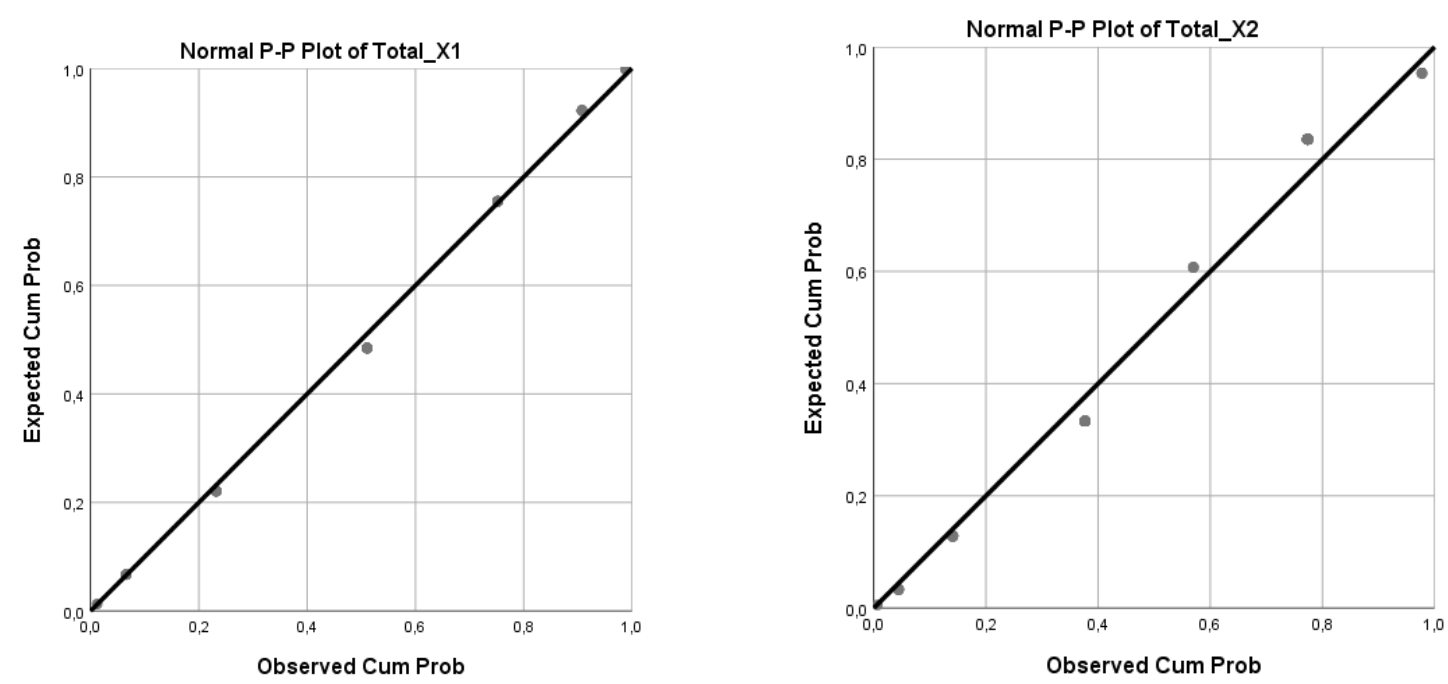


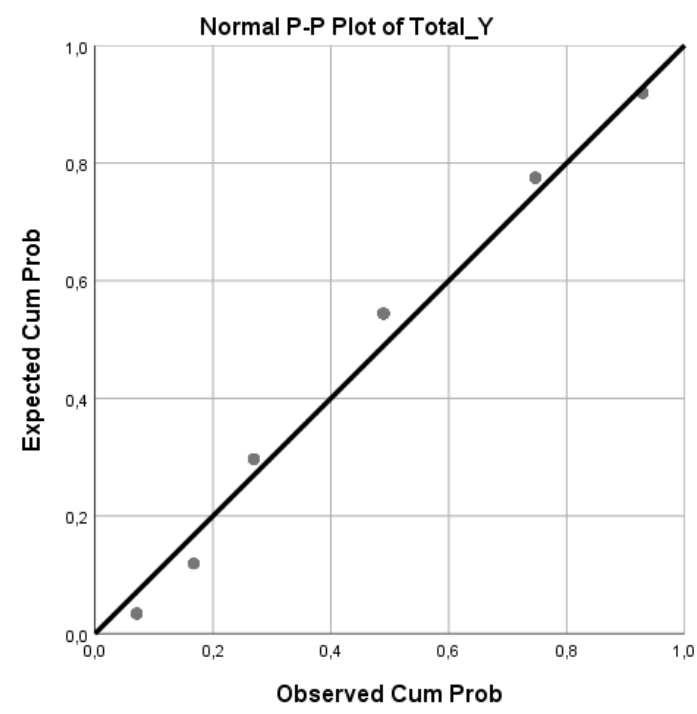

Gambar 1. Uji Normalitas Data

Sumber: hasil output SPSS for windows versi 25

Berdasarkan gambar uji normalitas menggunakan Normal P-Plot maka diketahui bahwa data dalam penelitian ini memiliki sebaran data yang normal. Semua data menyebar diskitar garis diagonal dan mengikuti arah garis diagonal, atau grafik histogramnya menunjukan pola distribusi normal, maka model regresi memenuhi asumsi normalitas. Dengan demikian, penelitian dengan analisis regresi berganda dapat dilakukan.

\subsection{Pengaruh Modal Usaha Terhadap Pengembangan Usaha Mikro di Kecamatan Kabila Kabupaten Bone Bolango}

Menurut Juliasty (2009), saat seseorang memutuskan untuk berwirausaha maka ia perlu memperhatikan aspek modal usaha. Hal ini penting, disamping perlu juga memperhatikan dan melengkapi aspek lain yaitu tenaga kerja, teknologi, sarana dan prasarana, dan lainnya. Jenis usaha yang dibuka akan menentukan modal usaha yang dibutuhkan, karena besaran modal usaha akan digunakan dalam banyak hal nantinya. Kemudian, selain jenis usaha modal juga dipengaruhi oleh timeline operasional dalam proses usahanya atau membuat produksi yang diinginkan. (Juliasty, 2009)

Dalam pandangan ekonomi Islam, modal harus terus menerus dikembangkan agar perputaran uang tidak akan berhenti. Karena apabila modal terhenti atau tertimbun maka tidak akan ada manfaat bagi orang lain dari harta tersebut, akan tetapi andai saja uang digunakan untuk melakukan kegiatan bisnis maka akan ada manfaat bagi orang lain dari uang tersebut. Modal diwajibkan kepada manusia untuk menggunakannya dengan sebaikbaiknya, agar terus berproduktif dan tidak habis digunakan. Untuk itu perlu adanya semangat kerja dari para pelaku usaha. Semangat kerja menjadi kekuatan bagi pekerja untuk mengeluarkan kemampuan kerja yang baik setiap harinya. (Pamungkas, 2019)

Berdasarkan hasil analisis, dapat diketahui bahwa Modal Usaha berpengaruh terhadap Pengembangan Usaha usaha mikro di Kecamatan Kabila Kabupaten Bone Bolango. Hasilnya dapat dilihat pada uji statistik berikut ini: 
Tabel 3. Analisis Regresi Modal Usaha Terhadap Pengembangan Usaha Mikro

\begin{tabular}{|c|c|c|c|c|c|c|}
\hline \multicolumn{7}{|c|}{ Coefficients $^{a}$} \\
\hline \multirow{2}{*}{\multicolumn{2}{|c|}{ Model }} & \multicolumn{2}{|c|}{$\begin{array}{c}\text { Unstandardized } \\
\text { Coefficients }\end{array}$} & \multirow{2}{*}{$\begin{array}{c}\text { Standardized } \\
\text { Coefficients }\end{array}$} & \multirow[b]{2}{*}{$\mathrm{t}$} & \multirow[b]{2}{*}{ Sig. } \\
\hline & & $\mathrm{B}$ & Std. Error & & & \\
\hline 1 & (Constant) & 2,555 & 1,715 & & 1,490 &, 140 \\
\hline & Modal_Usaha (X1) & 294 & ,111 & 269 & 2,656 & ,009 \\
\hline & $\begin{array}{l}\text { Strategi_Pemasaran } \\
\text { (X2) }\end{array}$ & ,397 & ,115 & ,351 & 3,459 & ,001 \\
\hline
\end{tabular}

a. Dependent Variable: Pengembangan_Usaha (Y)

Sumber: hasil output SPSS for windows versi 25

Berdasarkan tabel regresi di atas, yaitu konstanta a sebesar 2,555 dan koefisien b1 sebesar 0,294. Berdasarkan hasil tersebut maka diperoleh persamaan regresi sebagai berikut:

$$
\mathrm{Y}=\mathrm{a}+\mathrm{bX}_{1}
$$

\section{Pengembangan Usaha $=2,555+0.294$ Modal Usaha}

Berdasarkan persamaan regresi linier tersebut, diperoleh hasil nilai konstanta $(\alpha)$ yaitu 2,555 menunjukkan bahwa nilai pengembangan usaha pada saat modal usaha bernilai nol atau tetap, yaitu sebesar 2,555 dan bernilai positif. Selanjutnya, variabel modal usaha memiliki nilai koefisien sebesar 0,294 artinya setiap kenaikan modal usaha sebesar satu-satuan maka akan diikuti dengan kenaikan pengembangan usaha sebesar 0,294. Koefisien regresi b1 bernilai positif, artinya telah terjadi hubungan antara modal usaha dan pengembangan usaha. Semakin tinggi nilai modal usaha maka pengembangan usaha akan meningkat atau semakin baik.

Mengetahui pengaruh modal usaha terhadap pengembangan usaha, dilakukan melalui uji t berikut hasil yang diperoleh:

Tabel 4. Analisis Uji $t$ Modal Usaha Terhadap Pengembangan Usaha

Mikro

\begin{tabular}{|c|c|c|c|c|c|c|}
\hline \multicolumn{7}{|c|}{ Coefficients $^{\mathrm{a}}$} \\
\hline \multirow{2}{*}{\multicolumn{2}{|c|}{ Model }} & \multicolumn{2}{|c|}{$\begin{array}{l}\text { Unstandardized } \\
\text { Coefficients }\end{array}$} & $\begin{array}{c}\text { Standardized } \\
\text { Coefficients }\end{array}$ & \multirow[b]{2}{*}{$\mathrm{t}$} & \multirow[b]{2}{*}{ Sig. } \\
\hline & & $\mathrm{B}$ & Std. Error & Beta & & \\
\hline \multirow[t]{3}{*}{1} & (Constant) & 2,555 & 1,715 & & 1,490 & , 140 \\
\hline & Modal_Usaha (X1) & ,294 & ,111 & 269 & 2,656 &, 009 \\
\hline & $\begin{array}{l}\text { Strategi_Pemasaran } \\
\text { (X2) }\end{array}$ & ,397 & ,115 & ,351 & 3,459 & ,001 \\
\hline
\end{tabular}

a. Dependent Variable: Pengembangan_Usaha (Y)

Sumber: hasil output SPSS for windows versi 25

Berdasarkan table dijelaskan bahwa pengaruh variabel modal usaha terhadap pengembangan usaha didapatkan nilai thitung sebesar 2,656 sedangkan tabel sebesar 1,661 atau thitung $>t_{\text {tabel }}$ dan tingkat signifikansi $0,009<0,05$ dengan demikian dapat disimpulkan bahwa $\mathrm{H}_{1}$ diterima artinya secara parsial modal usaha berpengaruh secara signifikan terhadap pengembangan usaha. 
Hal ini menunjukkan bahwa secara parsial modal berpengaruh positif dan signifikan terhadap pengembangan usaha mikro di Kecamatan Kabila Kabupaten Bone Bolango. Hal ini berarti bahwa semakin besar modal yang mereka pakai maka semakin berkembang usaha yang mereka jalankan. Kebanyakan para pelaku usaha mikro di Kecamatan Kabila Kabupaten Bone Bolango memakai modal sendiri dalam memulai dan membangun usaha mereka. Usaha mikro yang mereka jalankan tergolong usaha paling kecil. Hal tersebut yang menyebabkan besar modal usaha yang mereka miliki sangat mempengaruhi berkembangnya usaha yang di jalankan.

Hasil penelitian ini sejalan dengan beberapa penelitian yang telah dilakukan sebelumnya, seperti penelitian (Vijaya \& Irwansyah, 2018), (Purwati, Purwa, \& Paramita, 2021), (Purwanti, 2013), (Savitri, 2018), (Pamungkas, 2019), (Abbas, 2018), (Putri, Pradhanawati, \& Prabawani, 2014), (Safitri \& Setiaji, 2018), dan (Istinganah \& Widiyanto, 2020) menunjukkan bahwa modal usaha berpengaruh positif terhadap pengambangan usaha.

\subsection{Pengaruh Strategi Pemasaran Terhadap Pengembangan Modal Usaha Mikro di Kecamatan Kabila Kabupaten Bone Bolango.}

Selain modal usaha, strategi pemasaran juga menjadi salah satu faktor penentu dalam proses keberhasilan perkembangan usaha. Pemasaran harus jelas konsepnya, arah pencapaiannya, dan seberapa besar peluang keberhasilannya. Strategi pemasaran merupakan siklus manajemen yang pada dasarnya harus memiliki perencanaan, kemudian pelaksanaan, menentukan price, promotion, distribution, dan selling sehingga tercipta pertukaran barang dan jasa dari produsen ke konsumen.

Strategi pemasaran adalah meninjau konsep bauran pemasaran. Menurut Kotler dan Armstrong dalam Ajuna (2020), bauran pemasaran itu adalah kumpulan alat pemasaran taktis terkontrol yang terintegrasi oleh perusahaan untuk menghasilkan respons yang diinginkan di pasar sasaran, dengan pendekatan pemasaran yang disebut 4P, yaitu Produk, harga, tempat, dan promosi. Manajemen pemasaran merupakan kegiatan penganalisaan, perencanaan, pelaksanaan, pengendalian. Program-program dibuat untuk membentuk, membangun dan memelihara segala keuntungan dari pertukaran melalui sasaran

Berdasarkan hasil analisis, dapat diketahui bahwa Strategi Pemasaran berpengaruh terhadap Pengembangan Usaha usaha mikro di Kecamatan Kabila Kabupaten Bone Bolango. Hasilnya dapat dilihat pada uji statistik berikut ini:

Tabel 5. Analisis Regresi Modal Usaha Terhadap Pengembangan Usaha Mikro

\begin{tabular}{|c|c|c|c|c|c|c|}
\hline \multicolumn{7}{|c|}{ Coefficients $^{a}$} \\
\hline & & \multicolumn{2}{|c|}{$\begin{array}{c}\text { Unstandardized } \\
\text { Coefficients }\end{array}$} & \multirow{2}{*}{$\begin{array}{c}\begin{array}{c}\text { Standardized } \\
\text { Coefficients }\end{array} \\
\text { Beta } \\
\end{array}$} & \multirow[b]{2}{*}{$\mathrm{t}$} & \multirow[b]{2}{*}{ Sig. } \\
\hline \multicolumn{2}{|c|}{ Model } & B & Std. Error & & & \\
\hline \multirow[t]{3}{*}{1} & (Constant) & 2,555 & 1,715 & & 1,490 &, 140 \\
\hline & Modal_Usaha (X1) & 294 & ,111 & 269 & 2,656 & ,009 \\
\hline & $\begin{array}{l}\text { Strategi_Pemasaran } \\
\text { (X2) }\end{array}$ & ,397 & ,115 &, 351 & 3,459 & ,001 \\
\hline
\end{tabular}

a. Dependent Variable: Pengembangan_Usaha (Y)

Sumber: hasil output SPSS for windows versi 25 
Berdasarkan tabel regresi di atas, yaitu konstanta a sebesar 2,555 dan koefisien b1 sebesar 0,397. Berdasarkan hasil tersebut maka diperoleh persamaan regresi sebagai berikut:

$$
\mathrm{Y}=\mathrm{a}+\mathrm{bX}_{1}
$$

\section{Pengembangan Usaha $=2,555+0.397$ Strategi Pemasaran}

Berdasarkan persamaan regresi linier tersebut, diperoleh hasil nilai konstanta $(\alpha)$ yaitu 2,555 menunjukkan bahwa nilai pengembangan usaha pada saat strategi pemasaran bernilai nol atau tetap, yaitu sebesar 2,555 dan bernilai positif. Selanjutnya, variabel strategi pemasaran memiliki nilai koefisien sebesar 0,397 artinya setiap kenaikan strategi pemasaran sebesar satu-satuan maka akan diikuti dengan kenaikan pengembangan usaha sebesar 0,397. Koefisien regresi b2 bernilai positif, artinya telah terjadi hubungan antara strategi pemasaran dan pengembangan usaha. Semakin tinggi nilai strategi pemasaran maka pengembangan usaha akan meningkat atau semakin baik.

Mengetahui pengaruh strategi pemasaran terhadap pengembangan usaha, dilakukan melalui uji t berikut hasil yang diperoleh:

Tabel 6. Analisis Uji $t$ Modal Usaha Terhadap Pengembangan Usaha Mikro

\begin{tabular}{|c|c|c|c|c|c|c|}
\hline \multicolumn{7}{|c|}{ Coefficients $^{\mathrm{a}}$} \\
\hline \multirow{2}{*}{\multicolumn{2}{|c|}{ Model }} & \multicolumn{2}{|c|}{$\begin{array}{l}\text { Unstandardized } \\
\text { Coefficients }\end{array}$} & \multirow{2}{*}{$\begin{array}{c}\text { Standardized } \\
\text { Coefficients }\end{array}$} & \multirow[b]{2}{*}{$\mathrm{t}$} & \multirow[b]{2}{*}{ Sig. } \\
\hline & & B & Std. Error & & & \\
\hline \multirow[t]{3}{*}{1} & (Constant) & 2,555 & 1,715 & & 1,490 &, 140 \\
\hline & Modal_Usaha (X1) & 294 & 111 & 269 & 2,656 & ,009 \\
\hline & $\begin{array}{l}\text { Strategi_Pemasaran } \\
\text { (X2) }\end{array}$ & ,397 & ,115 &, 351 & 3,459 & ,001 \\
\hline
\end{tabular}

a. Dependent Variable: Pengembangan_Usaha

Sumber: hasil output SPSS for windows versi 25

Hasil pengujian parsial (uji $t$ ) antara variabel strategi pemasaran terhadap pengembangan usaha mikro di Kecamatan Kabila Kabupaten Bone Bolango menunjukkan bahwa nilai thitung lebih besar dari Ttabel yaitu sebesar $2.656>1.661$. Dan memiliki nilai signifikan probabilitas sebesar 0.009 yang lebih kecil dari 0.05 , sehingga dapat disimpulkan $\mathrm{H} 2$ diterima artinya strategi pemasaran berpengaruh terhadap pengembangan usaha.

Hal ini menunjukkan bahwa secara parsial strategi pemasaran berpengaruh positif terhadap pengembangan usaha mikro di Kecamatan Kabila Kabupaten Bone Bolango. Hal ini dikarenakan mereka mempromosikan produk secara pribadi dan sederhana melalui postingan sosial media, dari mulut ke mulut, dan ada pula yang tidak melakukan promosi penjualan. Karena usaha mikro yang hanya tergolong usaha paling kecil belum bisa melakukan strategi pemasaran yang terlalu luas seperti yang dilakukanusaha berskala besar yaitu promosi lewat iklan, spanduk, banner, sponsor, give away, diskon, serta bergabung dalam suatu komunitas. Kemudian para usaha mikro hanya memiliki satu tempat penjualan, mereka menunggu pembeli di tempat penjualan dari produk yang dijual.

Penelitian ini sejalan dengan penelitian yang dilakukan oleh (Vijaya \& Irwansyah, 2018), (Purwati, Purwa, \& Paramita, 2021), (Purwanti, 2013), (Savitri, 2018), dan (Pamungkas, 2019) bahwa strategi pemasaran berpengaruh terhadap pengembangan modal usaha. Sedangkan penelitian (Hidayati \& Yoyok , 2016) menunjukkan. 


\subsection{Pengaruh Modal Usaha dan Strategi Pemasaran Terhadap Pengembangan Usaha Mikro di Kecamatan Kabila Kabupaten Bone Bolango}

Usaha Mikro Kecil dan Menengah (UMKM) memiliki peran yang besar dalam menopang pendapatan per kapita negara Indonesia, mengatasi kemiskinan, dan meningkatkan Pendapatan Domestik Bruto (PDB). Namun nyatanya, para wirausahawan di Indonesia masih kesulitan dalam mengembangan UMKM nya. Banyak faktor yang mempengaruhi seperti yang telah dijelaskan sebelumnya yaitu keterbatasan modal usaha, kualitas dan kuantitas SDM yang fokus pada pengembangan UMKM masih minim, strategi pemasaran dan produksi yang masih tradisional, tidak menguasai IT, dan pesaing yang kompetitif.

Maka perlu pengembangan usaha dengan mengatasi permasalahan-permasalahan di atas. Membantu ekspansi usaha dengan penyediaan modal usaha, pengembangan skill para wirausahawan, merancan strategi produksi dan pemasaran yang membantu efektivitas para wirausahawan, meningkatan kemampuan IT, dan bisa membaca dan menganalisis pesaing pasar. Hal ini dilakukan untuk mengembangkan UMKM.

Secara definisi pengembangan usaha merupakan upaya yang dilakukan dan dikoodinir oleh para pelaku usaha yang terlibat dalam usaha tersebut untuk mengekspansi barang dan jasa guna mempertahankan dan memperbaiki kualitas hidupnya (Hertia, 2018). Salah satu indikator pengembangan usaha berhasil ialah peningkatan penjualan. Ini menjadi faktor karena berarti wirausahawan tersebut sudah meningkatkan kemampuannya dengan pandai membaca pasar, mampu melakukan inovasi produk atau jasa, memiliki relasi yang kuat baik permodalan maupun pemasaran, dan memiliki strategi pemasaran yang inovatif (Purwanti, 2013).

Pengembangan usaha yang terdiri dari aspek strategi, manajemen pemasaran, dan penjualan. Pada aspek manajemen pemasaran, di mana strategi pemasaran sangat penting agar dapat menguasai pasar baik dalam negeri maupun luar negeri. Kemudian, aspek keuangan di mana modal sangat penting untuk melakukan pengembagan usaha. Untuk menambahkan modal bisa dari modal usaha sendiri atau mengunakan modal pinjaman dari pihak ketiga.

Dalam mengembangkan usaha, tentunya sangat diperlukan untuk meningkatkan permodalan. Besar kecilnya modal akan mempengaruhi perkembangan usaha dalam pencapaian pendapatan. Tak sedikit pemilik usaha yang berencana untuk mengembangkan usahanya harus terhambat karena permasalahan modal. Pada kenyataannya modal tidak hanya dibutuhkan pada saat awal mula berdirinya suatu perusahaan saja bahkan saat perusahaan sudah berjalan, suntikan modal juga dibutuhkan untuk mengembangkan suatu usaha. Maka bisa dikatakan kekuatan modal menentukan besar kecilnya sebuah bisnis. Sangat sulit menaikan omzet penjualan tanpa ada penambahan modal. (Alisaningtyas, 2020)

Lalu, strategi pemasaran adalah salah satu cara memenangkan keunggulan bersaing yang berkesinambungan baik itu untuk perusahaan yang memproduksi barang atau jasa. Strategi pemasaran dapat dipandang sebagai salah satu dasar yang dipakai dalam menyusun perencanaan perusahaan secara menyeluruh. (Nuraisiah, 2021)

Alasan lain yang menunjukkan pentingnya strategi pemasaran adalah semakin kerasnya persaingan yang dihadapi oleh perusahaan pada umumnya. Dalam situasi yang 
demikian, tidak ada lagi pilihan lain bagi perusahaan kecuali berusaha untuk menghadapinya atau sama sekali keluar dari arena persaingan. Oleh karenanya kreativitas dan inovasi diperlukan untuk bisa menguasai pangsa pasar. Dengan demikian usaha yang dijalankan akan berkembang. (Hertia, 2018)

Berdasarkan uraian teori di atas, dalam penelitian ini setelah dilakukan perhitungan statistik diperoleh bawah secara simultan modal usaha dan strategi pemasaran berpengaruh dalam pengembangan usaha. Hasilnya dapat dilihat pada perhitungan statistik di bawah ini:

Tabel 7. Analisis Koefisien Determinasi Modal Usaha dan Strategi Pemasaran terhadap Pengembangan Usaha

\begin{tabular}{|c|c|c|c|c|}
\hline \multicolumn{5}{|c|}{ Model Summary } \\
\hline Model & $\mathrm{R}$ & R Square & Adjusted R Square & $\begin{array}{l}\text { Std. Error of the } \\
\text { Estimate }\end{array}$ \\
\hline 1 &, $535^{a}$ & 286 & 271 & 1,324 \\
\hline
\end{tabular}

a. Predictors: (Constant), Modal_Usaha (X1), Strategi_Pemasaran (X2)

Sumber: hasil output SPSS for windows versi 25

Tabel di atas menunjukkan nilai koefisien determinasi, yaitu nilai yang menunjukkan seberapa besar variabel modal usaha dan strategi pemasaran berkontribusi dalam mempengaruhi pengembangan usaha. Hasil uji statistik tersebut diperoleh hasil 0,286 artinya sebesat $28,6 \%$ pengembangan usaha dipengaruhi oleh modal usah dan strategi pemasaran, sisanya sebesar 71,4\% dipengaruhi oleh variabel lain di luar penelitian ini seperti tenaga kerja, dan keuntungan yang didapat oleh pelaku usaha mikro itu sendiri. Dengan demikian variabel modal usaha dan strategi pemasaran berpengaruh rendah terhadap pengembangan usaha mikro.

Sedangkan hasil R Square pada penelitian ini tidak mendekati angka nol maupun angka satu. Jadi dikategorikan pada angka sedang yang artinya pengaruh variabel modal usaha dan strategi pemasaran rendah terhadap pengembangan usaha mikro.

Tabel 8. Analisis Korelasi Modal Usaha dan Strategi Pemasaran terhadap Pengembangan Usaha

\begin{tabular}{|c|c|c|c|c|}
\hline \multicolumn{5}{|c|}{ Model Summary } \\
\hline Model & $\mathrm{R}$ & R Square & Adjusted R Square & $\begin{array}{l}\text { Std. Error of the } \\
\text { Estimate }\end{array}$ \\
\hline 1 &, $535^{\mathrm{a}}$ & 286 & 271 & 1,324 \\
\hline
\end{tabular}

a. Predictors: (Constant), Modal_Usaha (X1), Strategi_Pemasaran (X2)

Sumber: hasil output SPSS for windows versi 25

Berdasarkan tabel, sesuai dengan hasil pengujian koefisien korelasi sebesar 0.535. Artinya bahwa terdapat hubungan yang sedang antara modal dan strategi pemasaran terhadap pengembangan usaha mikro, karena korelasi berada pada interval $0.40-0.599$.

Terakhir, untuk melihat pengaruh secara simultan yang ditimbulkan oleh modal usaha dan strategi pemasaran terhadap pengembangan usaha secara simultan, maka dianalisis menggunakan Uji F. Hasil uji F menunjukkan: 
Tabel 10. Analisis Uji F Persepsi dan Preferensi terhadap Sikap Nasabah

\begin{tabular}{|c|c|c|c|c|c|c|}
\hline \multicolumn{7}{|c|}{ ANOVAa $^{a}$} \\
\hline \multicolumn{2}{|c|}{ Model } & $\begin{array}{l}\text { Sum of } \\
\text { Squares }\end{array}$ & Df & Mean Square & $\mathrm{F}$ & Sig. \\
\hline \multirow[t]{3}{*}{1} & Regression & 63,376 & 2 & 31,688 & 18,065 &, $000^{\mathrm{b}}$ \\
\hline & Residual & 157,871 & 90 & 1,754 & & \\
\hline & \begin{tabular}{|l|} 
Total \\
\end{tabular} & 221,247 & 92 & & & \\
\hline
\end{tabular}

Sumber: hasil output SPSS for windows versi 20

Berdasarkan tabel diatas menunjukkan bahwa nilai $\mathrm{F}_{\text {hitung }}$ sebesar 18,065 dengan nilai signifikansi sebesar 0,000. Karena tingkat signifikansinya lebih kecil dari 0,05 maka H3 diterima dengan nilai $\mathrm{F}_{\text {hitung }}>\mathrm{F}_{\text {tabel }}(18.065>3,10)$ sehingga dapat dikatakan bahwa modal usaha dan strategi pemasaran berpengaruh.

\section{Kesimpulan}

Mengacu pada hasil penelitian yang telah dilakukan dengan menggunakan menyebar kuesioner pada 93 usaha mikro dan dilakukan uji statistik, diperoleh hasil yang mana; pertama, H1 diterima artinya modal usaha berpengaruh terhadap pengembangan usaha mikro di Kecamatan Kabila Kabupaten Bone Bolango, dengan perolehan $t$ hitung $>t$ tabel $=2.656>1.661$; kedua, H2 diterima artinya strategi pemasaran berpengaruh terhadap pengembangan usaha mikro di Kecamatan Kabila Kabupaten Bone Bolango, dengan perolehan $t$ hitung $>t$ tabel $=3.459>1.661$; dan ketiga, H1 diterima artinya modal usaha dan strategi pemasaran berpengaruh terhadap pengembangan usaha mikro di Kecamatan Kabila Kabupaten Bone Bolango, dengan perolehan $F$ hitung $>F$ tabel= $18.065>3,10$. Penelitian sekaligus memperkuat penelitian-penelitian yang dilakukan sebelumnya. Dengan demikian, pemerintah Kecamatan Kabila Kabupaten Bone Bolango jika ingin meningkatkan usaha 1205 usaha mikto yang ada maka harus memperkuat suntikan modal usaha dan memperbaiki strategi pemasaran yang telah ada, sehingga dapat mengembangkan usaha mikro yang ada

\section{REFERENSI}

Abbas, D. (2018). PENGARUH MODAL USAHA, ORIENTASI PASAR, DAN ORIENTASI KEWIRAUSAHAAN TERHADAP KINERJA UKM KOTA MAKASSAR. Jurnal Manajemen, Ide, Inspirasi (MINDS), 95-111.

Ajuna, L. H. (2020). The Effect of Marketing Mix Towards Decision of Muslim Consumers in Travelug. Jurnal Ilmiah Ekonomi Islam, 6(2), 246-250.

Alisaningtyas, E. F. (2020). PENGARUH KARAKTERISTIK WIRAUSAHA MODAL USAHA DAN STRATEGI PEMASARAN TERHADAP PERKEMBANGAN USAHA UMKM SARANG BURUNG WALLET DI DESA KEDIREN KECAMATAN KALITENGAH LAMONGAN. . Jurnal Ekonomi Mahasiswa: $J E K M A, 1(1)$.

Arkani, A., \& Muhibbin, M. (2021). The Effect of Service Quality and Results on Customer Satisfaction Mudharabah Savings in PT. Bank Syariah Mandiri Gorontalo Branch Office, Indonesia. alaa: Journal of Islamic Finance, 1(1), 17-25. 
Ayuwuragil, K. (2017, November 15). Kemenkop UKM: 3,79 Juta UMKM Sudah Go Online. Dipetik September 20, 2021, dari CNN Indonesia: https://www.cnnindonesia.com/ekonomi/20171115161037-78-

255819/kemenkop-ukm-379-juta-umkm-sudah-go-online

Hapsari, A. (2019). PRAKTEK KOMERSIALISASI LEMBAGA KEUANGAN MIKRO SYARIAH DALAM PANDANGAN ETIKA BISNIS ISLAM. JIMF (Jurnal Ilmiah Manajemen Forkamma), 2(1).

Hertia, D. (2018). Setiap Pembisnis Harus Punya Buku Ini. Jakarta: PT Elex Media Komputindo.

Hidayati, E. P., \& Yoyok , S. (2016). Pengaruh Modal Kerja Dan Strategi Pemasaran Terhadap Keberhasilan Usaha Kerajinan Manik-Manik Kaca Desa Plumbon Gambang Kecamatan Gudo Kabupaten Jombang. Jurnal Pendidikan Ekonomi (JUPE), 4(3).

Istinganah, N. F., \& Widiyanto, W. (2020). Pengaruh Modal Usaha, Tingkat Pendidikan, dan Karakteristik Wirausaha Terhadap Perkembangan UKM. Economic Education Analysis Journal, 9(2), 438-455.

Juliasty, S. (2009). Cerdas Mendapatkan dan Mengelola Modal Usaha. Jakarta: Balai Pustaka.

Nuraisiah, R. (2021). PENGARUH PENERAPAN STRATEGI PEMASARAN TERHADAP PERKEMBANGAN USAHA HOME INDUSTRI DI KOTA CILEGON PROVINSI BANTEN. Jurnal Manajemen Dan Bisnis, 3(01), 65-81.

Pamungkas, L. M. (2019). Pengaruh Modal Usaha, Strategi Pemasaran, dan Karakteristik Wirausaha Terhadap Pengembangan Usaha Mikro Kecil Menengah Perikanan di Kabupaten Tulungagung. Tulungagung: IAIN Tulungagung.

Purwanti, E. (2013). Pengaruh karakteristik wirausaha, modal usaha, strategi pemasaran terhadap perkembangan UMKM di Desa Dayaan dan Kalilondo Salatiga. Among Makarti, 5(1).

Purwati, D., Purwa, G. E., \& Paramita, D. P. (2021). PENGARUH KEMAMPUAN USAHA, MODAL USAHA DAN STRATEGI PEMASARAN TERHADAP KEBERHASILAN USAHA DENGAN PERKEMBANGAN USAHA SEBAGAI VARIABEL INTERVENING (Studi Kasus Pada Usaha Mikro Kecil Dan Menengah (UMKM) di Kawasan Desa Kedewan Kabupaten Bojonegoro). . Journal of Management, 7(1).

Putri, K., Pradhanawati, A., \& Prabawani, B. (2014). PENGARUH KARAKTERISTIK KEWIRAUSAHAAN, MODAL USAHA DAN PERAN BUSINESS DEVELOPMENT SERVICE TERHADAP PENGEMBANGAN USAHA (STUDI PADA SENTRA INDUSTRI KERUPUK DESA KEDUNGREJO SIDOARJO JAWA TIMUR. Jurnal Ilmu Administrasi Bisnis, 3(4).

Riyanti, D. B. (2003). Kewirausahaan dari Sudut Pandang Psikologi Kepribadian. Jakarta: Grasindo.

Safitri, H., \& Setiaji, K. (2018). Pengaruh Modal Usaha Dan Karakteristik Wirausaha Terhadap Perkembangan Usaha Mikro Dan Kecil Di Desa Kedungleper Kecamatan Bangsri Kabupaten Jepara. Economic Education Analysis Journal, 7(2), 792-800.

Sanawiri, B., \& Iqbal, M. (2018). Kewirausahaan. Malang: Universitas Brawijaya Press. 
Savitri, F. W. (2018). Pengaruh Modal Usaha, Kualitas Sumber Daya Manusia, dan Strategi Pemasaran terhadap Pengembangan UMKM di Desa Surub Kecamatan Surub Kabupaten Trenggalek. Tulungagung: IAIN Tulungagung.

Sururi, A., Hasanah, B., Mulyasih, R., Firdaus, I. A., Hasuri, H., \& Yuliani, H. (2020). PENINGKATAN KAPASITAS EKONOMI MASYARAKAT MELALUI PEMBERDAYAAN KELOMPOK USAHA MIKRO KECIL DAN MENENGAH DI KAWASAN PANTAI UTARA DESA DOMAS KABUPATEN SERANG. Kumawula: Jurnal Pengabdian Kepada Masyarakat, 3(3), 405-415.

Vijaya, P. D., \& Irwansyah, R. M. (2018). PENGARUH MODAL PSIKOLOGIS, KARAKTERISTIK WIRAUSAHA, MODAL USAHA DAN STARTEGI PEMASARAN TERHADAP PERKEMBANGAN USAHA UMKM DI KECAMATAN BULELENG TAHUN 2017. Ekuitas: Jurnal Pendidikan Ekonomi, 5(1), 45-51.

Widjadja, Y. R., Alamsyah, D. P., Rohaeni, H., \& Sukanjie, B. (2018). Peranan Kompetensi SDM UMKM Dalam Meningkatkan Kinerja UMKM Desa Cilayung Kecamatan Jatinangor, Sumedang. Jurnal Abdimas BSI: Jurnal Pengabdian Kepada Masyarakat, 1(3). 